\title{
Socio-demographic determinants of pregnancy termination among adolescent girls and young women in selected high fertility countries in sub-Saharan Africa
}

\author{
Bright Opoku Ahinkorah(B)
}

\begin{abstract}
Background: Most of the unintended pregnancies that occur among adolescent girls and young women (AGYW) in sub-Saharan Africa (SSA) end up in pregnancy termination. In this study, the socio-demographic determinants of pregnancy termination among AGYW (aged 15-24) in selected countries with high fertility rates in SSA were examined.

Methods: This was a cross-sectional analysis of data from the most recent Demographic and Health Surveys of nine countries in SSA. The countries included are Angola, Burkina Faso, Burundi, Chad, Gambia, Mali, Niger, Nigeria, and Uganda. A total of 62,747 AGYW constituted the sample size for the study. Fixed and random effects models were used to examine the determinants of pregnancy termination with statistical significance at $p<0.05$.

Results: Higher odds of pregnancy termination were found among AGYW aged 20-24, those who were cohabiting and married, those who listened to radio and watched television at least once a week and those who lived in communities with high literacy level. Conversely, the odds of pregnancy termination were lower among AGYW with three or more births and those with secondary/higher education.

Conclusion: The socio-demographic determinants of pregnancy termination among AGYW in this study were age, level of education, marital status, exposure to radio and television, parity, and community literacy level. The findings provide the needed information for designing health interventions to reduce unwanted pregnancies and unsafe abortions in countries with high fertility rates in SSA. It is recommended that governments and non-governmental organisations in these countries should enhance sexuality education and regular sensitization of adolescent sexual and reproductive health programmes targeted at AGYW who are at risk of pregnancy termination.
\end{abstract}

Keywords: Pregnancy termination, Adolescent girls, Young women, Sub-Saharan Africa, Reproductive health, Global Health

\section{Background}

One of the major reasons for the high fertility rates in most countries in sub-Saharan Africa (SSA) is that a considerable number of women in SSA are not contraceptive users [14]. Several obstacles to the use of contraception have been cited in a number of studies $[2,5,6]$. These obstacles

Correspondence: brightahinkorah@gmail.com

School of Public Health, Faculty of Health, University of Technology Sydney, Sydney, Australia

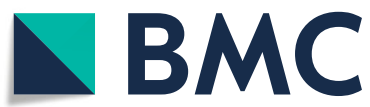

include inadequate knowledge on family planning methods and where they can be accessed, low quality and limited availability of family planning services, and high cost of family planning methods, services, travel, and time. Other obstacles centre around fear of side effects, disapproval from partners and family members, and concerns about moral and social acceptability $[2,5,6]$. These obstacles are more prevalent in adolescent girls and young women (AGYW), and contribute significantly to the high unmet

(c) The Author(s). 2021 Open Access This article is licensed under a Creative Commons Attribution 4.0 International License, which permits use, sharing, adaptation, distribution and reproduction in any medium or format, as long as you give appropriate credit to the original author(s) and the source, provide a link to the Creative Commons licence, and indicate if changes were made. The images or other third party material in this article are included in the article's Creative Commons licence, unless indicated otherwise in a credit line to the material. If material is not included in the article's Creative Commons licence and your intended use is not permitted by statutory regulation or exceeds the permitted use, you will need to obtain permission directly from the copyright holder. To view a copy of this licence, visit http://creativecommons.org/licenses/by/4.0/. The Creative Commons Public Domain Dedication waiver (http://creativecommons.org/publicdomain/zero/1.0/) applies to the data made available in this article, unless otherwise stated in a credit line to the data. 
need for contraception among this cohort of women $[2,6]$. This may explain the approximately 80 million mistimed and unplanned pregnancies, which occur in low-and middle-income countries, and constitute $40 \%$ of all pregnancies [7]. Majority of these mistimed and unplanned pregnancies end in abortions ( 40 million) and are responsible for the high burden of health and socio-economic challenges for many women and their families [7].

In SSA, previous studies on pregnancy termination among AGYW have identified socio-demographic factors such as age, ethnicity, parity, occupation, age at first sex, marital status, place of residence, and region as factors associated with pregnancy termination among AGYW [8-10]. These studies were done in countries with lower fertility rates compared to countries, which have higher fertility rates [11]. Despite evidence that women, particularly AGYW in countries with high fertility rates in SSA have high unmet need for contraception, leading to high unintended pregnancies and abortions $[2,6]$, studies that have examined the determinants of pregnancy termination among AGYW in countries with high fertility rates in SSA are scanty. Moreover, there has not been any pooled analysis of nationally representative data on the determinants of pregnancy termination among AGYW in countries with high fertility rates in SSA. This study, therefore, aims to fill this gap by examining the socio-demographic determinants of pregnancy termination among AGYW in selected countries with high fertility rates in SSA. This study is important because it provides the needed information for designing sexual and reproductive health interventions to reduce unwanted pregnancies and unsafe abortion in SSA.

\section{Methods}

\section{Data source}

This was a cross-sectional analysis of data from the most recent Demographic and Health Surveys (DHSs)
(2010-2019) of nine countries in SSA. The countries included are Angola, Burkina Faso, Burundi, Chad, Gambia, Mali, Niger, Nigeria, and Uganda (see Fig. 1). These countries were selected because they were ranked among the first ten countries in SSA with fertility rates above 5.0, a value that is higher than the rate of 4.7 in SSA and 2.4 globally [11]. The overarching objective of the DHSs is to generate demographic and health indicators that are nationally representative. They capture data on essential maternal and child health indicators, including pregnancy termination $[12,13]$.

\section{Sample and sampling strategy}

A two-stage stratified sampling procedure was used in sampling the participants for the DHS. Detailed information on the two-stage sampling procedure exist in previous studies [12,13]. A total of 62, 747 AGYW (aged 1524) were included in this study. Table 1 has comprehensive information on the sample.

\section{Study variables \\ Outcome variable}

The outcome variable in this study was pregnancy termination. Pregnancy termination in the DHS includes induced abortions, stillbirths and miscarriages. To derive this variable, survey participants were asked "have you ever had a pregnancy terminated?" Two responses emanated from this question "No" and "Yes". These two responses were used to define the outcome variable in line with previous studies [14-16].

\section{Explanatory variables}

The explanatory variables were grouped into individual level factors (age, marital status, level of education, wealth quintile, frequency of reading newspaper/ magazine, listening to radio and watching television, and parity) and contextual level factors (place of

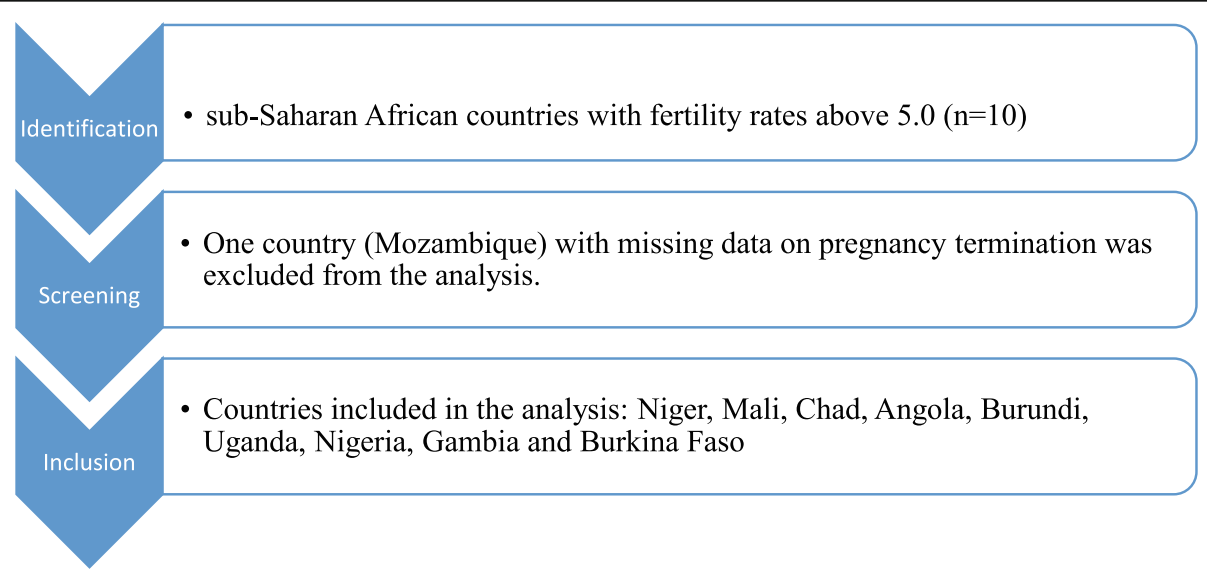

Fig. 1 Inclusion and exclusion criteria 
Table 1 Description of surveys and study sample

\begin{tabular}{llll}
\hline Country & Year of survey & Weighted sample $(\mathbf{n})$ & Weighted sample (\%) \\
\hline Angola & $2015-16$ & 6498 & 10.36 \\
Burkina Faso & 2010 & 6598 & 10.51 \\
Burundi & $2016-17$ & 7109 & 11.33 \\
Chad & $2014-15$ & 6846 & 10.91 \\
Gambia & 2013 & 4496 & 7.17 \\
Mali & 2018 & 4003 & 6.38 \\
Niger & 2012 & 3806 & 6.07 \\
Nigeria & 2018 & 15,297 & 24.38 \\
Uganda & 2016 & 8093 & 12.90 \\
Total & - & 62,747 & 100
\end{tabular}

residence, community literacy level, and community socio-economic status). The selection of these variables was based on their significant associations with pregnancy termination in previous studies [14-16] and their availability in the DHS datasets used in this study. The various categories used to describe each of these variables are in Tables 2 and 3. This study also adopted the categorization of the variables from previous studies $[6,17]$.

\section{Data analyses}

Using Stata 14.0, the analysis was performed by first calculating the prevalence of pregnancy termination and describing the characteristics of the participants using frequencies and percentages. Next, the distribution of the explanatory variables across pregnancy termination was done using Chi-square test with a statistical significance at $p<0.05$. Finally, a mixed effects analysis (fixed and random effects) was performed to examine determinants of pregnancy termination using four models (Model 0, 1, 2, and 3). Log likelihood and Akaike's Information Criterion (AIC) tests were used to check for model fitness while variations between models were assessed using the Intracluster Correlation Coefficient (ICC). Odds ratio with 95\% confidence intervals (CIs) were used to present the fixed effects results. Variance inflation factor (VIF) was used to check for multicollinearity and there was no evidence of multicollinearity. Sample weights were applied to all distributions and correction for the complex survey design was considered.

\section{Results}

\section{Descriptive results}

Approximately $5 \%$ of the AGYW reported pregnancy termination, with the higher prevalence in Niger (7.8\%) and a lowest prevalence in Gambia (2.9\%) (Fig. 2).

The distribution of pregnancy termination among AGYW in the selected high fertility countries in SSA by the explanatory variables is presented in Table 2. At the individual level, the modal categories for pregnancy termination were found among respondents aged 20-24 (8.5\%), those with no formal education (6.5\%), and those who were cohabiting (12.1\%). Similarly, pregnancy termination was frequent among AGYW with poor wealth quintile (6.0\%), those who never read newspaper/magazine (5.5\%), those who listened to radio at least once a week (5.6\%), those who never watched television (5.8\%), and those with two births (9.9\%). With the community level factors, the modal categories for pregnancy termination were found among AGYW who lived in the rural areas $(5.8 \%)$, those who lived in communities with low literacy level (6.2\%), and those who lived in communities with low socio-economic status (5.9\%).

\section{Socio-demographic determinants of pregnancy termination}

In terms of the random effects results, a log likelihood of $-10,855$ and an AIC of 21,776.4, was an indication that the best fit model was Model 3. With the fixed effects results for the individual level factors, higher odds of pregnancy termination were found among AGYW aged 20-24, AGYW who were cohabiting and married, those who listened to radio and watched television at least once a week. Conversely, the odd of pregnancy termination was lower among AGYW with three or more births and those with secondary/higher education. In terms of the community level factors, AGYW in communities with high literacy had higher odds for pregnancy termination than those in communities with low literacy level.

\section{Discussion}

The determinants of pregnancy termination among AGYW in selected countries with high fertility in SSA were examined in the current study. Respondents aged 15-19 and those who were single had higher odds of pregnancy termination. A previous study in SSA 
Table 2 Distribution of pregnancy termination among adolescent girls and young women by the explanatory variables (Weighted)

\begin{tabular}{|c|c|c|c|c|c|c|c|c|c|c|c|}
\hline \multirow{4}{*}{$\begin{array}{l}\text { Variables } \\
\text { Individual } \\
\text { level variables }\end{array}$} & \multirow{4}{*}{$\begin{array}{l}\text { Frequency } \\
\text { (n) }\end{array}$} & \multirow{4}{*}{$\begin{array}{l}\text { Percentage } \\
\text { (\%) }\end{array}$} & \multirow{2}{*}{\multicolumn{2}{|c|}{$\begin{array}{l}\text { Pregnancy } \\
\text { termination }\end{array}$}} & \multirow{6}{*}{$\begin{array}{l}p \text {-value } \\
\\
\\
p< \\
0.001\end{array}$} & \multirow{5}{*}{$\begin{array}{l}\text { (Continued) } \\
\text { Variables } \\
\text { Individual } \\
\text { level variables }\end{array}$} & \multirow{5}{*}{$\begin{array}{l}\text { Frequency } \\
\text { (n) }\end{array}$} & & & & \\
\hline & & & & & & & & \multirow{4}{*}{$\begin{array}{l}\text { Percentage } \\
\text { (\%) }\end{array}$} & \multirow{2}{*}{\multicolumn{2}{|c|}{$\begin{array}{l}\text { Pregnancy } \\
\text { termination }\end{array}$}} & \multirow[t]{4}{*}{$p$-value } \\
\hline & & & \multirow[t]{3}{*}{ Yes } & \multirow[t]{2}{*}{ No } & & & & & & & \\
\hline & & & & & & & & & Yes & No & \\
\hline \multirow[t]{2}{*}{ Age } & & & & & & & & & & & \\
\hline & & & & & & Two births & 8484 & 13.5 & 9.9 & 90.1 & \\
\hline $15-19$ & 33,492 & 53.4 & 2.4 & 97.6 & & \multirow{2}{*}{$\begin{array}{l}\text { Three or more } \\
\text { births }\end{array}$} & \multirow[t]{2}{*}{5842} & \multirow[t]{2}{*}{9.3} & \multirow[t]{2}{*}{8.6} & \multirow[t]{2}{*}{91.4} & \\
\hline $20-24$ & 29,255 & 46.6 & 8.5 & 91.5 & & & & & & & \\
\hline \multicolumn{2}{|l|}{ Level of education } & & & & \multirow[t]{4}{*}{$\begin{array}{l}p< \\
0.001\end{array}$} & $\begin{array}{l}\text { Contextual level } \\
\text { variables }\end{array}$ & & & & & \\
\hline No Education & 19,780 & 31.5 & 6.5 & 93.5 & & Place of residence & & & & & $\begin{array}{l}p< \\
0.001\end{array}$ \\
\hline Primary & 16,604 & 26.5 & 6.2 & 93.8 & & Uluban & 23133 & 369 & 43 & 957 & \\
\hline Secondary/Higher & 26,363 & 42.0 & 3.7 & 96.3 & & Durat & 23,133 & 30.9 & 4.3 & 30.1 & \\
\hline \multirow[t]{2}{*}{ Marital Status } & & & & & \multirow{5}{*}{$\begin{array}{l}p< \\
0.001\end{array}$} & kuldal & 39,014 & 03.1 & 3.8 & 94.2 & \\
\hline & & & & & & $\begin{array}{l}\text { Community literacy } \\
\text { level }\end{array}$ & & & & & $\begin{array}{l}p< \\
0.001\end{array}$ \\
\hline Single & 34,510 & 55.0 & 1.4 & 98.6 & & \multirow{3}{*}{$\begin{array}{l}\text { Low } \\
\text { Moderate } \\
\text { High }\end{array}$} & 20,879 & 33.3 & 6.2 & 93.9 & \\
\hline Cohabiting & 5870 & 9.4 & 12.1 & 87.9 & & & 20,635 & 32.9 & 5.2 & 94.8 & \\
\hline Married & 22,367 & 35.7 & 9.4 & 90.6 & & & 21,233 & 33.8 & 4.4 & 95.6 & \\
\hline Wealth quintile & & & & & \multirow[t]{4}{*}{$\begin{array}{l}p< \\
0.001\end{array}$} & \multicolumn{2}{|c|}{$\begin{array}{l}\text { Community socio-economic } \\
\text { status }\end{array}$} & & & & \multirow[t]{4}{*}{$\begin{array}{l}p< \\
0.001\end{array}$} \\
\hline Poorest & 10,302 & 16.4 & 6.1 & 94.0 & & \multirow{3}{*}{$\begin{array}{l}\text { Low } \\
\text { Moderate } \\
\text { High }\end{array}$} & \multirow{2}{*}{$\begin{array}{l}31,750 \\
8746\end{array}$} & 50.6 & 5.9 & 94.1 & \\
\hline Poorer & 11,844 & 18.9 & 6.0 & 94.0 & & & & 13.9 & 5.2 & 94.8 & \\
\hline Middle & 12,164 & 19.4 & 5.7 & 94.3 & & & 22,251 & 35.5 & 4.3 & 95.7 & \\
\hline
\end{tabular}

Table 2 Distribution of pregnancy termination among adolescent girls and young women by the explanatory variables (Weighted) (Continued)

Frequency of reading newspaper/magazine

$\begin{array}{lllll}\text { Not at all } & 52,322 & 83.4 & 5.5 & 94.5 \\ \begin{array}{l}\text { Less than once a } \\ \text { week }\end{array} & 5242 & 8.4 & 3.9 & 96.1 \\ \begin{array}{l}\text { At least once a } \\ \text { weak }\end{array} & 5182 & 8.3 & 4.0 & 96.0\end{array}$

weak

\section{Frequency of listening to radio}

$\begin{array}{lllll}\text { Not at all } & 26,172 & 41.7 & 5.0 & 95.0 \\ \begin{array}{l}\text { Less than once a } \\ \text { week }\end{array} & 12,319 & 19.6 & 5.1 & 94.9 \\ \begin{array}{l}\text { At least once a } \\ \text { week }\end{array} & 24,256 & 38.7 & 5.6 & 94.4\end{array}$

\section{Frequency of watching} television

$\begin{array}{lllll}\text { Not at all } & 35,436 & 56.5 & 5.8 & 94.2 \\ \begin{array}{l}\text { Less than once a } \\ \text { week }\end{array} & 8361 & 13.3 & 4.7 & 95.3 \\ \text { At least once a } & 18,951 & 30.2 & 4.4 & 95.6\end{array}$
weak

Parity

$\begin{array}{lllll}\text { Zero births } & 35,551 & 56.7 & 2.3 & 97.7 \\ \text { One birth } & 12,869 & 20.5 & 8.8 & 91.2\end{array}$

$p<$ 0.001

observed that pregnancy termination is low among adolescent girls and never married women [15]. Barriers to accessing sexual and reproductive health services, including contraception could be the reasons for this finding [18-20]. Specifically, AGYW in most countries in SSA are often denied access to family planning services due to negative socio-cultural norms and this increases their tendency of experiencing unintended pregnancies, which could end in abortion [21, 22]. Apart from abortion, miscarriages and stillbirths, which also constitute other forms of pregnancy termination have been found to be higher among never married adolescent girls due to stigma, which affect their emotional and psychological $\begin{array}{ll}p< & \text { health and low utilization of antenatal care services [23- }\end{array}$ 25].

Pregnancy termination was high among AGYW with no births compared to those with four or more births. Similar findings have been obtained in Ghana and Mozambique [14]. Possibly, AGYW with no pregnancy history might not have the readiness to give birth, espe$0.001 \quad$ cially when they are young and not married and hence may opt to have their pregnancies terminated while others may lose their pregnancies through miscarriages and stillbirths [16]. 
Table 3 Multilevel logistic regression models for the socio-demographic determinants of pregnancy termination

\begin{tabular}{|c|c|c|c|c|}
\hline Variables & $\begin{array}{l}\text { Model } 0 \\
\text { aOR[95\%Cl] }\end{array}$ & $\begin{array}{l}\text { Model } 1 \\
\text { aOR[95\%Cl] }\end{array}$ & $\begin{array}{l}\text { Model } 2 \\
\text { aOR[95\%Cl] }\end{array}$ & $\begin{array}{l}\text { Model } 3 \\
\text { aOR[95\%Cl] }\end{array}$ \\
\hline \multicolumn{5}{|l|}{ Fixed effects results } \\
\hline \multicolumn{5}{|l|}{ Individual level factors } \\
\hline \multicolumn{5}{|l|}{ Age } \\
\hline $15-19$ & & Reference & & Reference \\
\hline $20-24$ & & $2.34^{* * *}[2.12-2.59]$ & & $2.35^{* * *}[2.13-2.60]$ \\
\hline \multicolumn{5}{|l|}{ Level of education } \\
\hline No Education & & Reference & & Reference \\
\hline Primary & & $1.39^{* * *}[1.26-1.52]$ & & $1.13^{*}[1.02-1.26]$ \\
\hline Secondary/Higher & & $0.98[0.88-1.10]$ & & $0.80^{* *}[0.71-0.91]$ \\
\hline \multicolumn{5}{|l|}{ Marital status } \\
\hline Single & & Reference & & Reference \\
\hline Cohabiting & & $5.65^{* * *}[4.97-6.43]$ & & $6.29^{* * * *}[5.60-7.20]$ \\
\hline Married & & $6.22^{* * *}[5.39-7.18]$ & & $5.49^{* * *}[4.74-6.36]$ \\
\hline \multicolumn{5}{|l|}{ Wealth quintile } \\
\hline Poorest & & Reference & & Reference \\
\hline Poorer & & $0.96[0.86-1.08]$ & & $0.98[0.87-1.10]$ \\
\hline Middle & & $0.97[0.86-1.09]$ & & $1.00[0.88-1.13]$ \\
\hline Richer & & $0.90[0.79-1.02]$ & & $0.92[0.80-1.05]$ \\
\hline Richest & & $0.87[0.75-1.00]$ & & $0.87[0.72-1.04$ \\
\hline \multicolumn{5}{|c|}{ Frequency of reading newspaper/magazine } \\
\hline Not at all & & Reference & & Reference \\
\hline Less than once a week & & $1.01[0.86-1.19]$ & & $0.95[0.81-1.12]$ \\
\hline At least once a week & & $1.06[0.89-1.27]$ & & $1.02[0.85-1.23]$ \\
\hline \multicolumn{5}{|c|}{ Frequency of listening to radio } \\
\hline Not at all & & Reference & & Reference \\
\hline Less than once a week & & $1.16^{* *}[1.03-1.29]$ & & $1.18^{* *}[1.05-1.32]$ \\
\hline At least once a week & & $1.22^{* * *}[1.18-1.34]$ & & $1.20^{* * *}[1.09-1.32]$ \\
\hline \multicolumn{5}{|c|}{ Frequency of watching television } \\
\hline Not at all & & Reference & & Reference \\
\hline Less than once a week & & $0.96[0.85-1.09]$ & & $1.00[0.87-1.14]$ \\
\hline At least once a week & & $1.08[0.97-1.20]$ & & $1.13^{*}[1.01-1.28]$ \\
\hline \multicolumn{5}{|l|}{ Parity } \\
\hline Zero births & & Reference & & Reference \\
\hline One birth & & $1.13^{*}[1.01-1.27]$ & & $1.10[0.98-1.23]$ \\
\hline Two births & & $0.94[0.82-1.06]$ & & $0.89[0.78-1.01]$ \\
\hline Three or more births & & $0.73^{* * *}[0.64-0.85]$ & & $0.68^{* * *}[0.59-0.80]$ \\
\hline \multicolumn{5}{|l|}{ Contextual level factors } \\
\hline \multicolumn{5}{|l|}{ Place of residence } \\
\hline Urban & & & Reference & Reference \\
\hline Rural & & & $1.20^{* *}[1.08-1.33]$ & $1.07[0.95-1.20]$ \\
\hline \multicolumn{5}{|l|}{ Community literacy level } \\
\hline Low & & & Reference & Reference \\
\hline Moderate & & & $0.91^{*}[0.83-0.99]$ & $1.10[1.00-1.21]$ \\
\hline
\end{tabular}


Table 3 Multilevel logistic regression models for the socio-demographic determinants of pregnancy termination (Continued)

\begin{tabular}{|c|c|c|c|c|}
\hline Variables & $\begin{array}{l}\text { Model } 0 \\
\text { aOR[95\%Cl] }\end{array}$ & $\begin{array}{l}\text { Model } 1 \\
\text { aOR[95\%Cl] }\end{array}$ & $\begin{array}{l}\text { Model } 2 \\
\text { aOR[95\%Cl] }\end{array}$ & $\begin{array}{l}\text { Model } 3 \\
\text { aOR[95\%Cl] }\end{array}$ \\
\hline High & & & $0.80^{* * * *}[0.72-0.90]$ & $1.18^{*}[1.04-1.34]$ \\
\hline \multicolumn{5}{|c|}{ Community socio-economic status } \\
\hline Low & & & Reference & Reference \\
\hline Moderate & & & $0.89[0.80-1.00]$ & $0.98[0.86-1.10]$ \\
\hline High & & & $0.93[0.82-1.04]$ & $1.09[0.94-1.26]$ \\
\hline \multicolumn{5}{|l|}{ Random effects results } \\
\hline PSU Variance $(95 \% \mathrm{Cl})$ & $0.06(0.03-0.10)$ & $0.04(0.02-0.09)$ & $0.05(0.03-0.10)$ & $0.03(0.01-0.08)$ \\
\hline ICC & 0.2 & 0.01 & 0.02 & 0.01 \\
\hline LR Test & $\begin{array}{l}x^{2}=15.4 \\
p<0.001\end{array}$ & $\begin{array}{l}x^{2}=6.2 \\
p<0.05\end{array}$ & $\begin{array}{l}x^{2}=14.2 \\
p<0.001\end{array}$ & $\begin{array}{l}x^{2}=4.0 \\
p<0.05\end{array}$ \\
\hline Wald $x^{2}$ & Reference & $1982.9^{* * *}$ & $87.6^{* * *}$ & $2126.3^{* * *}$ \\
\hline \multicolumn{5}{|l|}{ Model fitness } \\
\hline Log-likelihood & $-12,320.6$ & $-10,945.1$ & $-12,275.7$ & $-10,855$ \\
\hline $\mathrm{AlC}$ & $24,645.3$ & $21,930.2$ & $24,565.3$ & $21,776.4$ \\
\hline Sample size & 62,747 & 62,747 & 62,747 & 62,747 \\
\hline Number of clusters & 1391 & 1391 & 1391 & 1391 \\
\hline \multicolumn{5}{|c|}{$\begin{array}{l}\text { Exponentiated coefficients; } 95 \% \text { confidence intervals in brackets; }{ }^{*} p<0.05, \stackrel{* * *}{p} p<0.01, \stackrel{* * *}{p} p<0.001 \\
\text { PSU Primary Sampling Unit, ICC Intracluster correlation coefficient, } L R \text { Test Likelihood ratio Test, AIC Akaike's Information Criterion, aOR adjusted Odds Ratios, Cl }\end{array}$} \\
\hline
\end{tabular}

AGYW with secondary/higher education also had lower odds of terminating their pregnancies compared to those with no formal education. In terms of the association between education and pregnancy termination, similar findings were obtained by Dickson, Adde [14] and Seidu, Ahinkorah [16]. Since pregnancy termination in the current study includes stillbirths and miscarriages, it is possible that AGYW with secondary/higher education may have the knowledge required to prevent these adverse pregnancy outcomes from occurring [26]. Moreover, higher levels of education may expose AGYW to the risks associated with induced abortions and hence

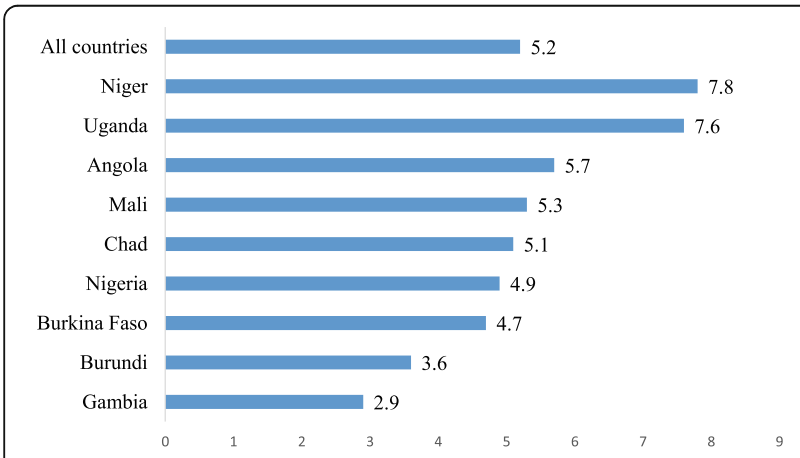

Fig. 2 Proportion of adolescent girls and young women who had experienced pregnancy termination in the selected countries with high fertility in sub-Saharan Africa may reduce their involvement in them. On the contrary, studies in China [27] and Ghana [28] found pregnancy termination to be high among women with higher educational level and argued that educated women may have pregnancies that interfere with their education and hence may decide to terminate those pregnancies. These findings may confirm the findings of the current study where AGYW who lived in high literacy communities had increased odds of pregnancy termination. In high literate communities, AGYW may have access to information on pregnancy termination and hence may act on the knowledge gained to seek abortion services. Such information may be available on radio and television, which have been found in the current study to increase the likelihood of pregnancy termination among those who are exposed compared to those who are not exposed. The disparities in findings could be due to the type of data used and the study population. While the current study and the studies by Dickson, Adde [14] and Seidu, Ahinkorah [16] used nationally-representative secondary data from the DHS, the studies that contradict the findings of the current study used primary data and focused on sub-sections of the population.

\section{Strengths and limitations}

This study is supported by the use of nationally representative large sample and reliable data. This makes it 
possible to generalise the findings to AGYW in other countries with high fertility. Notwithstanding, due to the cross-sectional nature of the surveys, this study cannot draw causal interpretations between the factors and pregnancy termination, at best only associations can be drawn. Secondly, pregnancy termination was selfreported and could have been prone to recall bias. Also, due the socio-cultural norms around pregnancy termination among AGYW, the respondents in this study may have under-reported pregnancy termination due to fear of stigma. Moreover, the data used were from different years and this may affect the generalizability of the findings. Finally, the sampling time is different between countries, which may cause a bias in comparing the findings between countries.

\section{Conclusion}

The socio-demographic factors associated with pregnancy termination among AGYW in this study were age, level of education, marital status, exposure to radio and television, parity, and community literacy level. The findings provide the needed information for designing health interventions to reduce unwanted pregnancies and unsafe abortions. It is recommended that governments and non-governmental organisations in these countries should enhance sexuality education and regular sensitization of adolescent sexual and reproductive health programmes targeted at AGYW who are at risk of pregnancy termination. Such interventions will contribute to the achievement of the Sustainable Development Goal 3.1 that seeks to reduce the global maternal mortality ratio to fewer than 70 per 100,000 live births by 2030 .

\section{Abbreviations}

AIC: Akaike's Information Criterion; aOR: Adjusted odds ratio;

AGYW: Adolescent girls and young women; DHS: Demographic and Health Survey; ICC: Intracluster Correlation Coefficient; SSA: Sub-Saharan Africa; VIF: Variance Inflation Factor

\section{Acknowledgements}

The author thanks the MEASURE DHS project for their support and for free access to the original data.

\section{Author's contributions}

$\mathrm{BOA}$ conceived and designed the study. BOA reviewed the literature and performed the analysis. BOA provided technical support and critically reviewed the manuscript for its intellectual content. BOA had final responsibility to submit for publication. The author read and amended drafts of the paper and approved the final version.

\section{Funding}

There was no funding for this study.

\section{Availability of data and materials}

The data for this study can be accessed on https://dhsprogram.com/data/ available-datasets.cfm.

\section{Declarations}

Ethics approval and consent to participate

Ethics approval was not required for this study since the data is secondary and is available in the public domain. More details regarding DHS data and ethical standards are available at: http://goo.gl/ny8T6X.

\section{Consent for publication}

No consent to publish was needed for this study, as the author did not use any details, images or videos related to individual participants. In addition, data used are available in the public domain

\section{Competing interests}

The author declares no competing interest.

Received: 16 September 2020 Accepted: 19 August 2021

Published online: 04 September 2021

\section{References}

1. Bongaarts J, Casterline J. Fertility transition: is sub-Saharan Africa different? Popul Dev Rev. 2013;38(Suppl 1):153.

2. Ahinkorah BO, Ameyaw EK, Seidu A-A, Agbaglo E, Budu E, Mensah F, et al. Sexual violence and unmet need for contraception among married and cohabiting women in sub-Saharan Africa: evidence from demographic and health surveys. PLoS One. 2020;15(11):e0240556.

3. Ahinkorah BO, Hagan JE Jr, Seidu A-A, Sambah F, Adoboi F, Schack T, et al. Female adolescents' reproductive health decision-making capacity and contraceptive use in sub-Saharan Africa: what does the future hold? PLoS One. 2020;15(7):e0235601.

4. Ahinkorah BO, Hagan JE, Seidu A-A, Hormenu T, Otoo JE, Budu E, et al., editors. Linking Female Adolescents' Knowledge, Attitudes and Use of Contraceptives to Adolescent Pregnancy in Ghana: A Baseline Data for Developing Sexuality Education Programmes. 2021: Multidisciplinary Digital Publishing Institute.

5. Sedgh G, Ashford LS, Hussain R. Unmet need for contraception in developing countries: examining women's reasons for not using a method, vol. 2. New York: Guttmacher Institute; 2016. p. 2015-6.

6. Ahinkorah BO. Predictors of unmet need for contraception among adolescent girls and young women in selected high fertility countries in sub-Saharan Africa: a multilevel mixed effects analysis. PLoS One. 2020;15(8): e0236352.

7. Singh S, Darroch JE. Adding it up: costs and benefits of contraceptive services: Guttmacher Institute and UNFPA; 2012. p. 1269-86.

8. Ahinkorah BO, Seidu A-A, Hagan JE, Archer AG, Budu E, Adoboi F, et al., editors. Predictors of Pregnancy Termination among Young Women in Ghana: Empirical Evidence from the 2014 Demographic and Health Survey Data 2021: Multidisciplinary Digital Publishing Institute.

9. Gilano G, Hailegebreal S. Determinants of abortion among youth 15-24 in Ethiopia: A multilevel analysis based on EDHS 2016. PloS one. 2021;16(3): e0248228.

10. Baruwa OJ, Amoateng AY, Biney E. Induced abortion in Ghana: prevalence and associated factors. J Biosoc Sci. 2021;1-12. https://doi.org/10.1017/ S0021932020000772

11. Total Fertility Rate 2020 [Internet]. 2020 [cited 30th April 2020]. Available from: https://worldpopulationreview.com/countries/total-fertility-rate/\#data Table.

12. Corsi DJ, Neuman M, Finlay JE, Subramanian SV. Demographic and health surveys: a profile. Int J Epidemiol. 2012;41(6):1602-13.

13. Seidu A-A, Darteh EKM, Kumi-Kyereme A, Dickson KS, Ahinkorah BO. Paid sex among men in sub-Saharan Africa: analysis of the demographic and health survey. SSM-Popul Health. 2019;11:1-11.

14. Dickson KS, Adde KS, Ahinkorah BO. Socio-economic determinants of abortion among women in Mozambique and Ghana: evidence from demographic and health survey. Arch Pub Health. 2018;76(1):37.

15. Seidu A-A, Ahinkorah BO, Ameyaw EK, Hubert A, Agbemavi W, ArmahAnsah EK, et al. What has women's reproductive health decision-making capacity and other factors got to do with pregnancy termination in subSaharan Africa? Evidence from 27 cross-sectional surveys. PLoS One. 2020 15(7):e0235329.

16. Seidu A-A, Ahinkorah BO, Agbemavi W, Amu H, Bonsu F. Reproductive health decision-making capacity and pregnancy termination among 
Ghanaian women: analysis of the 2014 Ghana demographic and health survey. J Public Health. 2019;29:1-10.

17. Ahinkorah BO. Individual and contextual factors associated with mistimed and unwanted pregnancies among adolescent girls and young women in selected high fertility countries in sub-Saharan Africa: a multilevel mixed effects analysis. PLoS One. 2020;15(10):e241050.

18. Bankole A, Malarcher S. Removing barriers to adolescents' access to contraceptive information and services. Stud Fam Plan. 2010;41(2):117-24.

19. Chandra-Mouli V, McCarraher DR, Phillips SJ, Williamson NE, Hainsworth G. Contraception for adolescents in low and middle income countries: needs, barriers, and access. Reprod Health. 2014;11(1):1.

20. Thatte N, Bingenheimer JB, Ndiaye K, Rimal RN. Unpacking the barriers to reproductive health services in Ghana: HIV/STI testing, abortion and contraception. Afr J Reprod Health. 2016;20(2):53-61.

21. Munakampe MN, Zulu JM, Michelo C. Contraception and abortion knowledge, attitudes and practices among adolescents from low and middle-income countries: a systematic review. BMC Health Serv Res. 2018;18(1):909.

22. Challa S, Manu A, Morhe E, Dalton VK, Loll D, Dozier J, et al. Multiple levels of social influence on adolescent sexual and reproductive health decisionmaking and behaviors in Ghana. Women Health. 2018;58(4):434-50.

23. Ahinkorah BO, Seidu A-A, Ameyaw EK, Budu E, Bonsu F, Mwamba B. Beyond counting induced abortions, miscarriages and stillbirths to understanding their risk factors: analysis of the 2017 Ghana maternal health survey. BMC Pregnancy Childbirth. 2021;21(1):1-10.

24. Ahinkorah BO. Intimate partner violence against adolescent girls and young women and its association with miscarriages, stillbirths and induced abortions in sub-Saharan Africa: evidence from demographic and health surveys. SSM-Popul Health. 2021;13:1-7.

25. Ahinkorah BO, Seidu A-A, Appiah F, Oduro JK, Sambah F, Baatiema L, et al. Effect of sexual violence on planned, mistimed and unwanted pregnancies among women of reproductive age in sub-Saharan Africa: a multi-country analysis of demographic and health surveys. SSM-Popul Health. 2020;11:1-8.

26. Ameyaw EK, Ahinkorah BO, Seidu A-A. Does knowledge of pregnancy complications influence health facility delivery? Analysis of 2014 Bangladesh demographic and health survey. PLoS One. 2020;15(8):e237963.

27. Gao GP, Zhang RJ, Zhang XJ, Jia XM, Li XD, Li X, et al. Prevalence and associated factors of induced abortion among rural married women: a crosssectional survey in a nhui, C hina. J Obstet Gynaecol Res. 2015;41(3):383-91.

28. Klutsey EE, Ankomah A. Factors associated with induced abortion at selected hospitals in the Volta region, Ghana. Int J Women's Health. 2014;6:809.

\section{Publisher's Note}

Springer Nature remains neutral with regard to jurisdictional claims in published maps and institutional affiliations.

Ready to submit your research? Choose BMC and benefit from:

- fast, convenient online submission

- thorough peer review by experienced researchers in your field

- rapid publication on acceptance

- support for research data, including large and complex data types

- gold Open Access which fosters wider collaboration and increased citations

- maximum visibility for your research: over $100 \mathrm{M}$ website views per year

At $\mathrm{BMC}$, research is always in progress.

Learn more biomedcentral.com/submissions 